\title{
Effects of quantitative feed restriction on the performance of broiler chickens
}

\author{
D. M. N. D. Dissanayake and L. S. David*
}

Department of Animal Science, Faculty of Agriculture, Eastern University, Sri Lanka, Chankaldy.

\begin{abstract}
A study was conducted to evaluate the effect of quantitative feed restriction on the performance and the production cost of broiler chickens. A total of 120, Indian River, day-old broiler chicks were randomly allocated into four dietary treatment groups such as 100\% diet as control treatment and $90 \%, 80 \%$ and $70 \%$ diets, in floor pens. All treatments were replicated thrice with 10 birds each in a Completely Randomized Design. Broiler chickens were fed broiler starter diet from day 1 to day 21 and broiler finisher diet from day 22 to day 42. The results revealed that the body weight gain in the birds fed with $90 \%$ diet was significantly higher than those of control diet during finisher and overall phases and vice-versa during starter period. The feed intakes of birds were significantly decreased with the severity of feed restriction during all periods. However, significantly the lowest overall feed conversion ratio was reported in the birds fed with $70 \%$ diet. Furthermore, higher relative liver and lung weights were observed in the control treatment while they had lower relative heart weight. The spleen was significantly increased in the birds fed with $90 \%$ diet. It could be concluded that giving $90 \%$ of the recommended diet to the broiler chickens increases growth, immunity and income.
\end{abstract}

Keywords: Broiler, body weight, carcass, cost, feed

\section{Introduction}

Growth performance of broiler chickens has been increased spectacularly over the last 30 years mainly due to the genetic progress, improvements of nutrition and controlled environment so that it takes only 33 days to reach finishing body weight of about $2 \mathrm{~kg}$ (Wilson, 2005). Unfortunately, this growth rate is accompanied by increased body fat deposition, high mortality and high incidence of metabolic diseases and skeletal disorders (Zubair and Leeson, 1996). These situations most commonly occur with broilers that consume feed ad libitum when compared to feed restricted birds (Nir et al., 1996). Thus feed restriction has been proposed to reduce these problems. Feed restriction programs used to reduce abdominal and carcass fat in broiler chickens rely on the phenomenon called compensatory growth to produce market body weight similar to control groups and to reduce high feed cost for broiler feeds. An enhanced rate of growth, exceeding the normal rate of gain, occurs when growth has been retarded by nutritional deprivation and followed by ad libitum feeding (Mc Murtry et al., 1988). Feed restriction programs are strategies that can be used to alter feeding management in order to decrease feed consumption to some extent and thereby growth rate, alleviating the occurrence of metabolic disorders and improving feed efficiency. Research in feed restriction has shown the potential to decrease the occurrence of ascites (Julian, 1997), and sudden death syndrome (Gonzales et al., 1998b). Physical feed restriction, lighting programs, and chemical methods are some of the procedures used to manipulate feed intake. In this context, this experiment was designed with an objective to study the effects of quantitative feed restriction on the performance and the cost of production of broiler chickens.

Received 19 April 2017. Accepted 13 July 2017. Corresponding author ${ }^{*}$ : alshiromi@yahoo.co.uk 


\section{Materials and Methods}

The experiment was carried out at Livestock Farm of the Department of Animal Science, Faculty of Agriculture, Eastern University, Sri Lanka for a period of 42 days. A total of 120, unisex, Indian River, day-old broiler chicks were obtained from commercial hatchery and allocated into four treatment groups in a Complete Randomized Design. Commercial broiler starter and finisher diets were fed to the birds as control treatment $\left(\mathrm{T}_{1}\right)$ with other three experimental diets such as $90 \%\left(\mathrm{~T}_{2}\right), 80 \%$ $\left(\mathrm{T}_{3}\right)$ and $70 \%\left(\mathrm{~T}_{4}\right)$ of the control diet as shown in Table 1. A two phase feeding program was adopted, where the broiler chickens were fed broiler starter mash crumbles from day 1 to day 21 and broiler finisher mash pellets from day 22 to day 42. Water was provided ad libitum in round type waterers throughout the period.

The chicks were brooded together in floor pens for one week and thereafter randomly divided into four treatments and three replicates. Each replicate the brooder was $0.023 \mathrm{~m}^{2}$ per chick. Electric bulbs of 40 watts were used as heating source per pen. During first 3 days the chicks were kept on papers instead of litter. The feed and water were offered to chicks using round feeders and round waters, respectively. Light was provided for 24 hours for the first week of rearing. The floor space per bird given from day 8 up to day 28 was $0.069 \mathrm{~m}^{2}$ and day 29 up to day 42 was $0.09 \mathrm{~m}^{2}$. The day temperature throughout the experimental period was ranged from $30-$ $36^{\circ} \mathrm{C}$.

Performances of broiler chickens were determined by measuring body weight, total feed consumption, feed conversion ratio (FCR), and dressing percentage. The body weights and feed intake of birds were recorded weekly. The FCR was calculated by dividing the total quantity of feed consumed by the total gain in body weight. At the end of the experiment the birds were starved for 12 hours to empty the crop of the bird at slaughtering time. Thereafter, all the birds were weighed and slaughtered. After removing feathers along with the skin, head, legs and all internal organs, the carcass weight was taken to determine the dressing percentage. Dressing percentage was calculated as a percentage of dress weight to the live weight of birds.

The weights of gizzard, spleen, heart, liver, bursa and lungs were measured using digital balance. The relative weights of organs were calculated as a percentage of organ weight to the live weight of birds and expressed as $\mathrm{g} / 100 \mathrm{~g}$ body weight. The collected data were computed and subjected to analysis of variance (ANOVA) using SAS statistical software (version 9.1) and difference between means were separated using the Duncan multiple range test (DMRT) at $5 \%$ significance level. 
Table 1. Feeding chart of broiler chickens

\begin{tabular}{|c|c|c|c|c|}
\hline Day & Control (g) & $\begin{array}{c}90 \% \text { of control } \\
(\mathrm{g})\end{array}$ & $\begin{array}{c}80 \% \text { of control } \\
(\mathrm{g})\end{array}$ & $\begin{array}{c}70 \% \text { of control } \\
(\mathrm{g})\end{array}$ \\
\hline 1 & 10.0 & 9.0 & 8.0 & 7.0 \\
\hline 2 & 12.0 & 10.8 & 9.6 & 8.4 \\
\hline 3 & 15.0 & 13.5 & 12.0 & 10.5 \\
\hline 4 & 20.0 & 18.0 & 16.0 & 14.0 \\
\hline 5 & 22.0 & 19.8 & 17.6 & 15.4 \\
\hline 6 & 27.0 & 24.3 & 21.6 & 18.9 \\
\hline 7 & 32.0 & 28.8 & 25.6 & 22.4 \\
\hline 8 & 36.0 & 32.4 & 28.8 & 25.2 \\
\hline 9 & 38.0 & 34.2 & 30.4 & 26.6 \\
\hline 10 & 39.0 & 35.1 & 31.2 & 27.3 \\
\hline 11 & 43.0 & 38.7 & 34.4 & 30.1 \\
\hline 12 & 45.0 & 40.5 & 36.0 & 31.5 \\
\hline 13 & 49.0 & 44.1 & 39.2 & 34.3 \\
\hline 14 & 52.0 & 46.8 & 41.6 & 36.4 \\
\hline 15 & 55.0 & 49.5 & 44.0 & 38.5 \\
\hline 16 & 60.0 & 54.0 & 48.0 & 42.0 \\
\hline 17 & 65.0 & 58.5 & 52.0 & 45.5 \\
\hline 18 & 70.0 & 63.0 & 56.0 & 49.0 \\
\hline 19 & 76.0 & 68.4 & 60.8 & 53.2 \\
\hline 20 & 83.0 & 74.7 & 66.4 & 58.1 \\
\hline 21 & 91.0 & 81.9 & 72.8 & 63.7 \\
\hline 22 & 93.0 & 83.7 & 74.4 & 65.1 \\
\hline 23 & 95.0 & 85.5 & 76.0 & 66.5 \\
\hline 24 & 97.0 & 87.3 & 77.6 & 67.9 \\
\hline 25 & 98.0 & 88.2 & 78.4 & 68.6 \\
\hline 26 & 100.0 & 90.0 & 80.0 & 70.0 \\
\hline 27 & 101.0 & 90.9 & 80.8 & 70.7 \\
\hline 28 & 103.0 & 92.7 & 82.4 & 72.1 \\
\hline 29 & 110.0 & 99.0 & 88.0 & 77.0 \\
\hline 30 & 117.0 & 105.3 & 93.6 & 81.9 \\
\hline 31 & 125.0 & 112.5 & 100.0 & 87.5 \\
\hline 32 & 133.0 & 119.7 & 106.4 & 93.1 \\
\hline 33 & 140.0 & 126.0 & 112.0 & 98.0 \\
\hline 34 & 148.0 & 133.2 & 118.4 & 103.6 \\
\hline 35 & 150.0 & 135.0 & 120.0 & 105.0 \\
\hline 36 & 151.0 & 135.9 & 120.8 & 105.7 \\
\hline 37 & 152.0 & 136.8 & 121.6 & 106.4 \\
\hline 38 & 153.0 & 137.7 & 122.4 & 107.1 \\
\hline 39 & 154.0 & 138.6 & 123.2 & 107.8 \\
\hline 40 & 156.0 & 140.4 & 124.8 & 109.2 \\
\hline 41 & 158.0 & 142.2 & 126.4 & 110.6 \\
\hline 42 & 160.0 & 144.0 & 128.0 & 112.0 \\
\hline
\end{tabular}

Source: Department of Animal Production and Health 


\section{Results and discussion}

\section{Growth performance}

Table 2 shows the effect of quantitative feed restriction on the growth performance of broiler chickens. There was significant difference recorded among the treatments for the body weight gain during 0-21, 22-42 and 0-42 days.

The results revealed that the birds fed with $90 \%$ of the control diet $\left(\mathrm{T}_{2}\right)$ recorded significantly the highest $(\mathrm{p}<0.05)$ body

Table 2. Body weight, feed intake and FCR of broiler chicken (Mean \pm Standard error)

\begin{tabular}{ccccr}
\hline Growth phase & $\mathrm{T}_{1}$ & $\mathrm{~T}_{2}$ & $\mathrm{~T}_{3}$ & $\mathrm{~T}_{4}$ \\
\hline \multicolumn{5}{c}{ Bodyweight gain (g) } \\
$0-21 \mathrm{~d}$ & $674 \pm 8.8^{\mathrm{a}}$ & $621 \pm 3.3^{\mathrm{b}}$ & $578 \pm 5.7^{\mathrm{c}}$ & $533 \pm 2.8^{\mathrm{d}}$ \\
$22-42 \mathrm{~d}$ & $1320 \pm 15.3^{\mathrm{c}}$ & $1486 \pm 29.1^{\mathrm{a}}$ & $1420 \pm 0.0^{\mathrm{b}}$ & $1348 \pm 15.9^{\mathrm{c}}$ \\
$0-42 \mathrm{~d}$ & $1988 \pm 0.0^{\mathrm{b}}$ & $2124 \pm 44.1^{\mathrm{a}}$ & $1998 \pm 5.7^{\mathrm{b}}$ & $1881 \pm 14.5^{\mathrm{c}}$ \\
\multicolumn{5}{c}{ Feed intake (g) } \\
$0-21 \mathrm{~d}$ & $930 \pm 2.8^{\mathrm{a}}$ & $840 \pm 2.8^{\mathrm{b}}$ & $752 \pm 1.1^{\mathrm{c}}$ & $658 \pm 1.1^{\mathrm{d}}$ \\
$22-42 \mathrm{~d}$ & $2344 \pm 2.3^{\mathrm{a}}$ & $2224 \pm 2.3^{\mathrm{b}}$ & $2155 \pm 2.8^{\mathrm{c}}$ & $1885 \pm 2.8^{\mathrm{d}}$ \\
$0-42 \mathrm{~d}$ & $3274 \pm 2.3^{\mathrm{a}}$ & $3064 \pm 2.3^{\mathrm{b}}$ & $2907.0 \pm 1.1^{\mathrm{c}}$ & $2543 \pm 1.0^{\mathrm{d}}$ \\
& & FCR & \\
$0-21 \mathrm{~d}$ & $1.39 \pm 0.02^{\mathrm{a}}$ & $1.35 \pm 0.01^{\mathrm{b}}$ & $1.30 \pm 0.01^{\mathrm{c}}$ & $1.23 \pm 0.01^{\mathrm{d}}$ \\
$22-42 \mathrm{~d}$ & $1.77 \pm 0.02^{\mathrm{a}}$ & $1.48 \pm 0.03^{\mathrm{bc}}$ & $1.51 \pm 0.00^{\mathrm{b}}$ & $1.39 \pm 0.01^{\mathrm{c}}$ \\
$0-42 \mathrm{~d}$ & $1.65 \pm 0.01^{\mathrm{a}}$ & $1.44 \pm 0.03^{\mathrm{b}}$ & $1.45 \pm 0.00^{\mathrm{b}}$ & $1.35 \pm 0.01^{\mathrm{c}}$ \\
\hline
\end{tabular}

Mean values within a row having different superscripts are significantly different Treatments: $\mathrm{T}_{1}$-Control diet $(100 \%), \mathrm{T}_{2}-90 \%$ of control diet, $\mathrm{T}_{3}-80 \%$ of control diet, $\mathrm{T}_{4}-70 \%$ of control diet

weight gain during finisher and overall phase when compared to others although the birds of control treatment $\left(\mathrm{T}_{1}\right)$ recorded significantly the highest $(\mathrm{p}<0.05)$ body weight gain during the starter period. In addition, significantly the lowest overall body weight gain was reported from the birds fed with $70 \%$ diet $\left(\mathrm{T}_{4}\right)$.

The results related to the feed intake revealed that the birds fed with control $\operatorname{diet}\left(\mathrm{T}_{1}\right)$ recorded significantly the highest $(\mathrm{p}<0.05)$ feed intake during starter, finisher and overall periods. The feed intakes of birds were significantly decreased with the severity of feed restrictions among the treatments during all periods $(0-21 d, 22-42 d$ and $0-42 d)$. The results of FCR revealed that the birds fed with control diet $\left(\mathrm{T}_{1}\right)$ have significantly the highest $(p<0.05)$ FCR during starter, finisher and overall periods while those fed with $70 \%$ diet $\left(\mathrm{T}_{4}\right)$ have significantly the lowest $(p>0.05)$ FCR.

These results showed that the broilers kept under $10 \%$ feed reduction than the recommended (control) amount increased weight gain by $5.9 \%$ when compared to the control. It has been known that feed restricted birds consumed more feed in their attempt to compensate for the time they would have been deprived of feed (Khetani et al., 2009). In contrast, Palo et al. (1995) observed that feed restricted birds gained less weight than full-fed control birds. The possible explanation of the lower body weight observed in the feed restricted birds may be the decrease in 
nutrient intake compared to the ad libitum fed birds. However, Ballay et al. (1992) observed no significant difference between the feed restricted and control birds for body weight gain, FCR and feed intake.

The highest FCR in birds fed with control $\left(\mathrm{T}_{1}\right)$ diet and the lowest FCR in birds fed with $70 \%$ diet $\left(\mathrm{T}_{4}\right)$ could be due to significantly higher and lower feed intakes of birds, respectively. The results indicate an improved feed utilization in restricted birds when compared to the control group. However, Khetani et al. (2009) indicated that feed restricted birds consumed more feed in their attempt to compensate for the time they would have been deprived of feed, thus, birds were less efficient in feed utilization and in the process did exhibit compensatory growth. Mahmood et al. (2007) and Onbasilar et al. (2009) have reported better FCR values in feed-restricted birds. When birds are subjected to early feed restriction they exhibit slow growth followed by a period of rapid growth and weight gain as they approach market weight to compensate for the delayed growth during early restriction period (Gous and Cherry, 2004). This translates into reduced maintenance requirements and improved feed utilization potential by birds due to smaller body weights (Lippens et al., 2000). Live weights, carcass weights and
dressing percentages

Table 3 shows the effect of quantitative feed restriction on the live weight, carcass weight and dressing percentage of broiler chickens. The results revealed that the birds fed with $90 \%$ diet $\left(\mathrm{T}_{2}\right)$ have significantly the highest live and carcass weights $(p<0.05)$ while those fed with $70 \%$ diet $\left(T_{4}\right)$ have the lowest $(p>0.05)$. This could be due to the significantly higher bodyweight gain and lower FCR in the birds fed with $90 \%$ diet when compared to the control.

Table 3. Live weight, carcass weight and dressing percentages

\begin{tabular}{lcccc}
\hline Parameter & T1 & T2 & T3 & T4 \\
\hline Live weight $(\mathrm{g})$ & $2030^{\mathrm{b}} \pm 10.0^{\mathrm{b}}$ & $2166 \pm 44.1^{\mathrm{a}}$ & $2040 \pm 5.8^{\mathrm{b}}$ & $1923 \pm 14.5^{\mathrm{c}}$ \\
Carcass weight $(\mathrm{g})$ & $1320^{\mathrm{c}} \pm 11.5^{\mathrm{cb}}$ & $1466 \pm 34.8^{\mathrm{a}}$ & $1350 \pm 26.5^{\mathrm{b}}$ & $1243 \pm 24.0^{\mathrm{c}}$ \\
$\begin{array}{l}\text { Dressing } \\
\text { percentage(\%) }\end{array}$ & $65 \pm 0.3$ & $67 \pm 1.2$ & $66 \pm 1.4$ & $64 \pm 1.6$ \\
\hline
\end{tabular}

Mean values within a row having different superscripts are significantly different

Treatments: $\mathrm{T}_{1}$-Control diet $(100 \%), \mathrm{T}_{2}-90 \%$ of control diet, $\mathrm{T}_{3}-80 \%$ of control diet, $\mathrm{T}_{4}-70 \%$ of control diet

According to Scheideler and Baughman (1993) there was significant effect of feed restriction on the carcass weight of broiler chickens. It is generally accepted that after restriction, compensatory growth will be attained. However, Summers et al. (1990) investigated a $50 \%$ feed restriction

program in 5-11-day-old broilers and did not report significant differences in carcass weight, whereas in other feed restriction studies carcass weight was increased (Tumova et al., 2002). However, the dressing percentage was not significantly different among treatments by the feed restriction in broiler chickens. Saleh et al. (1996) showed a trend of increasing dressing percentage for the restricted birds as well as improvement in breast meat yield. According to Saleh et al. (2005) dressing percentage was significantly reduced by feed restriction. 


\section{Relative organ weights of broiler Chicken.}

Table 4 shows the effect of quantitative feed restriction on the relative organ weights of broiler chick

Table 4. Relative organs weight of broiler chicken (Mean \pm standard error)

\begin{tabular}{lllll}
\hline $\begin{array}{l}\text { Relative organ } \\
\text { weight } \\
\text { (g/100g live } \\
\text { body weight) }\end{array}$ & $\mathbf{T}_{1}$ & $\mathbf{T}_{2}$ & $\mathbf{T}_{3}$ & $\mathbf{T}_{4}$ \\
\hline Gizzard & $2.02 \pm 0.04^{\mathrm{c}}$ & $2.20 \pm 0.06^{\mathrm{b}}$ & $2.05 \pm 0.01^{\mathrm{c}}$ & $2.35 \pm 0.02^{\mathrm{a}}$ \\
Heart & $0.35 \pm 0.01^{\mathrm{b}}$ & $0.42 \pm 0.00^{\mathrm{a}}$ & $0.42 \pm 0.00^{\mathrm{a}}$ & $0.43 \pm 0.01^{\mathrm{a}}$ \\
Liver & $2.04 \pm 0.01^{\mathrm{a}}$ & $1.75 \pm 0.05^{\mathrm{b}}$ & $1.59 \pm 0.07^{\mathrm{bc}}$ & $1.42 \pm 0.1^{\mathrm{c}}$ \\
Spleen & $0.07 \pm 0.00^{\mathrm{b}}$ & $0.12 \pm 0.01^{\mathrm{a}}$ & $0.07 \pm 0.01^{\mathrm{b}}$ & $0.09 \pm 0.07^{\mathrm{b}}$ \\
Bursa & $0.04 \pm 0.00^{\mathrm{c}}$ & $0.04 \pm .0 .01^{\mathrm{c}}$ & $0.04 \pm 0.09^{\mathrm{b}}$ & $0.05 \pm 0.01^{\mathrm{a}}$ \\
Lungs & $0.56 \pm 0.01^{\mathrm{a}}$ & $0.51 \pm 0.01^{\mathrm{b}}$ & $0.49 \pm 0.01^{\mathrm{b}}$ & $0.46 \pm 0.00^{\mathrm{c}}$ \\
\hline
\end{tabular}

Mean values within a row having different superscripts are significantly different

Treatments: $\mathrm{T}_{1}$-Control diet $(100 \%), \mathrm{T}_{2}-90 \%$ of control diet, $\mathrm{T}_{3}-80 \%$ of control diet, $\mathrm{T}_{4}-70 \%$ of control diet

The birds in control treatment $\left(\mathrm{T}_{1}\right)$ have significantly higher $(\mathrm{p}<0.05)$ relative liver and lung weights while they have significantly lower relative heart weight when compared to others. The spleen was significantly increased in the birds fed with $90 \%$ diet whereas bursa was significantly increased in the birds fed with $80 \%$ and $70 \%$ diet when compared to the control. Moreover, the relative gizzard weight was significantly increased in the birds fed with $70 \%$ diet.

The results revealed that feed restriction improves the immunity of broiler chickens by increasing the weights of immune organs. The findings of the present study correspond with David and Subalini (2015) who reported that relative gizzard weight decreases when feeding ad libitum. However, this result is not consistent with another research study (Summers et al., 1990), in which a significant difference was not observed in gizzard weight between birds. The reason for the lower relative heart weight of birds in control $\left(\mathrm{T}_{1}\right)$ treatment may be due to the lower body weight gain and higher FCR in birds which in turn could have affected the relative heart weight. In addition, the feed restricted birds tend to move around for searching feed and this might create increased physical activity in birds which in turn leads to increase heart rate in feed restricted birds. These results agree with that of McGovern et al. (1997), who concluded that heart weight was significantly higher in feed restricted broilers. Moreover, Hollands et al. (1965) reported that liver, heart and spleen weight were not affected in the birds on feed restriction program. In contrast, Onbasilar et al. (2009) reported a significantly lower heart weight in feed restricted broilers when compared to the unrestricted control.

In broilers, the liver is the main site of lipid production, whereas fatty tissue, especially in the abdomen, is the main site for fat storage (Leenstra, 1986). Feed restriction reduces metabolic efficiency of the liver; thus, the effect of the intensity and duration of restriction may cause a reduction in liver weight (Jones et al., 1995). This could be the reason for the 
lower relative liver weightsobserved in the birds of restricted treatment groups when compared to that of control treatment. However, after the rehabilitation period, some authors reported a liver enlargement (Ozdogan and Aksit, 2003). Anexplanation for this is that after the cessation of restricted feeding, birds will overeat, such that the liver will enlarge.

\section{Total feed cost, income and profit.}

Table 5 shows the effect of quantitative feed restriction on the total cost, income and profit from the broiler chicken production. The results indicate that there are significant differences among the treatments for the cost of feed, income and profit. In addition, the results indicate that, profit from the feed restricted birds were significantly higher than the control. This might be due to the higher feed cost obtained in control treatment than the feed restricted groups. Furthermore, a significantly the highest income was obtained from the birds fed $90 \%$ diet (T2) than others and this could be due to the higher growth performance of birds recorded in the birds fed $90 \%$ diet.

Table 5. Total feed cost, income and profit (Mean \pm standard error)

\begin{tabular}{cccc}
\hline Treatment & $\begin{array}{c}\text { Cost of feed } \\
\text { (SLR) }\end{array}$ & $\begin{array}{c}\text { Income } \\
\text { (SLR) }\end{array}$ & $\begin{array}{c}\text { Profit } \\
\text { (SLR) }\end{array}$ \\
\hline T1 & $351.36 \pm 0.06^{\mathrm{a}}$ & $551.1 \pm 5.88^{\mathrm{bc}}$ & $199.7 \pm 5.88^{\mathrm{b}}$ \\
T2 & $316.26 \pm 0.49^{\mathrm{b}}$ & $616.0 \pm 14.60^{\mathrm{a}}$ & $299.7 \pm 14.60^{\mathrm{a}}$ \\
T3 & $281.07 \pm 0.37 \mathrm{c}$ & $567.0 \pm 11.10^{\mathrm{b}}$ & $285.9 \pm 11.10^{\mathrm{a}}$ \\
T4 & $245.97 \pm 0.37^{\mathrm{d}}$ & $522.2 \pm 10.10^{\mathrm{c}}$ & $276.1 \pm 10.10^{\mathrm{a}}$ \\
\hline
\end{tabular}

Mean values within a column having different superscripts are significantly different

Treatments: T1-Control diet (100\%), T2-90\% of control diet, T3-80\% of control diet, T4-70\% of control diet SLR: Sri Lankan Rupees

The economic relevance of these results is that feed costs declined with the severity of the restriction since feed intake declined correspondingly. Feed restricted birds generally eat less than unrestricted birds (Saleh et al., 1996). However, cost of production was not inversely related to profit or profit/ $\mathrm{kg}$ live weight because normally final live weight of restricted birds was significantly less than $(\mathrm{P}<0.05)$ unrestricted except birds mildly restricted.

\section{Conclusion}

By giving $90 \%$ of the recommended diet to the broiler chickens, the body weight gain, live weight and carcass weight could be

increased. Furthermore, the immunity of broiler chickens could be increased by means of increasing spleen weight in broiler chickens as a result of $10 \%$ feed restriction. Moreover, the income and profit could be increased due to reducing $10 \%$ feed.

\section{References}

Ballay, M., Dunnington, E.A., Gross, B.W. and Siegel, P.B. (1992). Restricted feeding and broiler performance: age at initiation and length of restriction, Poultry Science $\mathbf{7 1}$ 440-447.

David, L.S. and Subalini, E. (2015). Effects of Feed restriction on the growth performance, organ size and carcass characteristics of Broiler chickens, Scholars Journal of Agriculture and Veterinary Sciences 2(2A):108-111. 
Gonzales, E., Buyse, J., Sayuri Takita, T., Sartori, J. R. and Decuypere, E. (1998b). Metabolic disturbances in male broilers of different strains. $1 . \quad$ Performance, mortality, and right ventricular hypertrophy, Poultry Science 77:1646-1653.

Gous, R. M. and Cherry, P. (2004). Effects of body weight at, and lighting regimen and growth curve to, 20 weeks on laying performance in broiler breeders, British Poultry Science 4(4): 452-454.

Hollands, K. G., Gowe, R. S. and Morse, P. M. (1965). Effects of food restriction on blood pressure, heart rate and certzin organ weights of the chicken. British Poultry. Science 6:297.

Jones, F. T., Anderson, K. E. and Ferket, P. R. (1995). Effect of extrusion on feed characteristics and broiler chicken performance, Journal of Applied Poultry. Research 4:300- 309.

Julian, R. J. (1997). Causes and prevention of ascites in broilers, Zootec. Int. 452-53.

Khetani, T. L., Nkukwana, T. T., Chimonyo, M. and Muchenje, V. (2009). Effect of quantitative feed restriction on broiler performance, Tropical Animal Health and Production 41:379-384.

Leenstra, F. R. (1986). Effect of age, sex, genotype, and environment on fat deposition of broiler chickens, World Poultry Science 42:12-25.

Lippens, M., Room, G., De Groote, G. and Decuypere, E. (2000): Early and temporary quantitative food restriction of broiler chickens. 1. Effects on performance characteristics, mortality and meat quality, British Poultry Science 41:343-354.

Mahmood, S., Mehmood, S., Ahmad, F., Masood, A. and Kausar, R. (2007). Effects of feed restriction during starter phase on subsequent growth performance, dressing percentage, relative organ weight and immune response of broilers, Pakistan Veterinary Journal 27:137-141.

McGovern, R. H., Robinson, F. E. and Feddes, J. J. R. (1997). Advances in ascites research, Zootc. Int 8:16-17.

MC Murtry, J. P., Rosebrough, R.W., Plavnik, I. and Cartwright, A.I. (1988): Influence of early plane of nutrition on enzyme systems and subsequent tissue deposition. pp. 329-341In: Biomechanisms Regulating Growth and Development (G. L. Steffens and T. S. Rumsey,ed). Betsville Symposia on Agricultural Research, Klumer Academic Publishers, Dordrecht, the Netherlands.

Nir, I., Nitsan, Z., Dunnington, E.A. and Siegel, P.B. (1996). Aspects of food intake in young domestic fowl: Metabolic and genetic considerations World Poultry Science 52:251-266.

Onbasilar, E. E., Yalcin, S., Torlak, E. and Ozdemir, P. (2009): Effects of early feed restriction on live performance, carcass characteristics, meat and liver composition, some blood parameters, heterophile lymphocyte ratio, antibody production and tonic immobility duration, Trop. Anim. Health and Production 41:15131519.

Ozdogan, M. and Aksit, M. (2003). Effects of feeds containing different fats on carcass and blood parameters of broilers, Journal of Applied Poultry Research 12:251256.

Palo, P. E., Sell, J. L., Piquer, F. J., Vilaseea, L. and Soto-Salanova, M. F. (1995). Effect of early nutrient restriction on broiler chickens performance and digestive enzyme activities, Poultry Science 74:14701483.

Saleh, K., Attia, Y. A. and Younis, H. (1996). Effect of feed restriction and breed on compensatory growth, abdominal fat and some production traits of broiler 
chicks, Archiv flir Geflugelkunde 60:153159.

Saleh, E. A., Watkins, S. E., Waldroup, A. L. and Waldroup, P. W. (2005). Effects of early feed restriction of live performance and carcass composition of male broilers grown for further processing, Poultry Science Association 14:87-93.

Scheideler, S. E. and Baughman, G. R. (1993). Computerized early feed restriction programs for various strains of broilers, Poultry Science 72:236-242.

Summers, J. D., Spratt, D. and Atkinson, J.L. (1990). Restricted feeding and compensatory growth for broilers, Poultry Science 69:225-229.
Tumova, E., Skrivan, M., Skrivanova, V. and Kacerovska, L. (2002). Effect of early feed restriction on growth in broiler chickens, turkeys and rabbits, Czech Journal of Animal Science 47(10):418-428.

Wilson, M. (2005). Production focus (In; Balancing genetics, welfare and economics in broiler production). 1(1): 1. Publication of Cobb-Vantress,Inc.

Zubair, A. K. and Leeson, S. (1996). Changes in body composition and adipocyte cellularity of male broilers subjected to varying degrees of early-life feed restriction, Poultry Science 75:719728. 